\title{
COVID-19 Reinfection: Myth or Truth?
}

\author{
Sayak Roy ${ }^{1}$ \\ Accepted: 22 May 2020 / Published online: 29 May 2020 \\ (C) Springer Nature Switzerland AG 2020
}

\begin{abstract}
The novel coronavirus disease (COVID-19) has posed a large problem to this world and has exposed the skeleton of healthcare system all over. There have been reports of patients getting reinfected with COVID-19 as they tested positive for the virus again after discharge. We try to address the issue of this reinfection and want to clarify whether this entity actually exists or is it just a myth.
\end{abstract}

Keywords COVID-19 - Reinfection

Novel coronavirus disease (COVID-19) or SARS-CoV-2 as it is now called has been playing havoc on the world economy, society, and health due to the pandemic nature of this new virus and has been associated with a case fatality rate of $6.81 \%$ as of April 20 (2,314,621 confirmed cases and 157,847 deaths) [1]. The severity and fatality out of COVID-19 are many with advanced age leading the way followed by cardiovascular disease, hypertension, chronic kidney disease, cancer, and many others [2]. It has been reported that the virus persists in sputum or feces for few weeks after the patients are discharged from the hospital [3], and there were reports from 22 patients in Beijing of the presence of the virus in the sputum for 39 days after they became negative in pharyngeal swab raising the question about the proper specimen to be tested. Similar fecal persistence has been seen in another study where they found the virus to be persistently present in the fecal matter although they did not find the marker of fecal-oral transmission which is the presence of replication-competent virus in fecal swabs [4]. Already there are known 80 distinct genotypical variants of this virus as per another study [5] which raises the concern for effective vaccine production and also might contribute to the various variations of presentations in different countries. We have also seen a case report stating the change of oropharyngeal swab

This article is part of the Topical Collection on Covid-19

Sayak Roy

sayak.roy.123@gmail.com

1 Department of Internal Medicine, Medica Superspecialty Hospital, 2/ J, Lenin Sarani, Serampore, Kolkata, West Bengal 712203, India during the convalescence period into positive for SARS-CoV2 RNA [6] when her real-time PCR report showed a viral load of $4.56 \times 10^{2}$ copies $/ \mathrm{mL}$ after two consecutive days of negative reports. The reasons for this sudden positive report amidst the negative reports are only speculative and can be anything from sampling error, unknown spike in viral load without symptoms during convalescence, specimen error, and so on. To add to this dilemma, in another study [7], it was seen that those who retested positive for SARS-CoV-2 RNA after discharge were generally young and had mild COVID-19 disease in the hospital and they did not show any disease progression when readmitted. The close contacts with these patients did not test positive, and the most important point that was noted was the use of commercially available kits during their discharge which showed negative results and the same patient tested positive in a hypersensitive method questioning the effectiveness and reliability of the kits used commercially. This brings up the issue of using more sensitive RNA detection methods before discharging a patient, and also samples should be taken from two different sites on two consecutive days, and then they must be corroborated. There had been a case report of three patients who were readmitted to Tongji Hospital between March 10 to March 20, 2020, after being discharged with IgM-negative and IgG-positive antibody response and RNA was non-detectable, but they were again readmitted without any symptoms because of the new SARS-CoV-2 RNA test showing positive results, while the $\mathrm{IgM}$ and $\mathrm{IgG}$ remained negative and positive respectively [8]. On further analysis of these three cases, it was found that the CT thorax findings were resolving during the readmission phase than their previous admission times, and the finding of this positive RNA test was found without the presence of 
Table 1 Specimen collection as per site of respiratory tract

\begin{tabular}{ll}
\hline Site of respiratory tract & Specimen type \\
\hline Upper respiratory tract & $\begin{array}{l}\text { Nasopharyngeal swab/oropharyngeal swab; } \\
\text { nasal mid-turbinate swab; anterior nares specimen; } \\
\text { nasopharyngeal wash/aspirate } \\
\text { Bronchoalveolar lavage, tracheal aspirate; sputum }\end{array}$ \\
\hline
\end{tabular}

evidence of contagiousness of viral RNA genetic fragments. Among the other possible reasons in this case report were recurrence of viral RNA material due to the detoxification process, sampling or technical errors during collection or transport, and also silent carrier state formation with continued passage, and hence, it suggested a14-day post-discharge period of quarantine for COVID-19 patients.

\section{Method of Swab Collection and Swab Detection of SARS-CoV-2 in Different Biological Specimens}

The proper methods of swab collection have been beautifully discussed by Petruzzi et al. [9] where it is suggested to perform the nasopharyngeal swab sampling by introducing the swab stick into the nasal cavity reaching to the level of posterior rhinopharyngeal tonsil region along an imaginary line joining the ear and the nostril with the patient seated comfortably with the head resting against the headrest. They described the process of oropharyngeal sampling by directing the swab towards the posterior part of the oropharynx and then rotating it a few times prior to removal. The swabs need to be inserted in the same tube while breaking the swab rod with a controlled and swift movement, and lastly we have to reset the cap. Upper respiratory tract samples like these should be collected within a few days of onset of symptoms as the highest titers of RNA are reached within 7-10 days of symptom onset and declines thereafter [10]. The virus can be isolated from various sites of the body, and the concentration varies from 1 day to another resulting in variation of positivity. A study [11] conducted on 205 patients with 1070 specimens showed the highest percentage of positive rate from bronchoalveolar lavage (BAL) specimen (93\%), followed by sputum (72\%), nasal swab (63\%), fibrobronchoscope brush biopsy (46\%), pharyngeal swab (32\%), feces (29\%), and blood $(1 \%)$. It must be noted that the specimens collected from patients for BAL were all having severe disease which itself increases the chance of getting positive results. Another study also shared a similar view with the abovementioned study and concluded that nasal swab will give a better yield than an oral swab and should be corroborated with other specimens if symptoms are suggestive, but the initial results come negative [12]. Since we have seen from the above discussion that the results of swab testing depend on many factors including time of swab procurement after initial symptom onset, site of the swab, transport of swab, and techniques used in swab collection, clinicians must not rule out COVID-19 in a highly suspected patient coming from an epidemic zone [13]. Grossly respiratory specimen collections to perform RT-PCR can be divided into two broad categories depending upon the site of the collection-upper respiratory specimen and lower respiratory specimen as shown in Table 1 [14].

In summary, Table 2 gives us an idea on various swabs that can be collected which may help us make judgments on which swabs should be tested at what time for getting highest positive yields [15].

\section{Comparative Value of Swab Test and CT Lesions}

A retrospective radiological study by Chen et al. assessed twenty-one COVID-19-positive patients having pneumonia from January 19, 2020, to February 20, 2020, who underwent
Table 2 Types of swabs that can be tested and the time period of getting positive results, highest peak reached, and time of fall

\begin{tabular}{llll}
\hline $\begin{array}{l}\text { Type of swab used for } \\
\text { RT-PCR }\end{array}$ & $\begin{array}{l}\text { Starts to peak from } \\
\text { (day) }\end{array}$ & $\begin{array}{l}\text { Highest levels } \\
\text { detected }\end{array}$ & Starts to fall \\
\hline $\begin{array}{c}\text { Nasal } \\
\text { Mid-turbinate } \\
\text { swab } \\
\text { Anterior nares } \\
\text { swab }\end{array}$ & Day 1 & First week & Third week onwards \\
$\begin{array}{l}\text { Oropharyngeal swab } \\
\text { Rectal }\end{array}$ & $\begin{array}{l}\text { Day 1 } \\
\text { End of first week }\end{array}$ & $\begin{array}{l}\text { First week } \\
\text { Second week }\end{array}$ & $\begin{array}{l}\text { Third week onwards } \\
\text { End of third week } \\
\text { onwards }\end{array}$ \\
\hline
\end{tabular}

RT-PCR, reverse transcription-polymerase chain reaction 
Table 3 Comparison of CT chest and RT-PCR reports in patients having COVID-19

\begin{tabular}{lllll}
\hline Name of author & Number of total patients & $\begin{array}{l}\text { Mean age of the } \\
\text { cohort (years) }\end{array}$ & $\begin{array}{l}\text { Percentage of RT-PCR } \\
\text { positivity at onset }\end{array}$ & $\begin{array}{l}\text { Percentage of CT chest } \\
\text { abnormality in very early days }\end{array}$ \\
\hline Ai et al. [18] & 1014 & $51 \pm 15$ & $59 \%$ & $88 \%$ \\
Fang et al. [19] & 51 & $45 \pm 10$ & $71 \%$ & $98 \%$ \\
Bernheim et al. [21] & 121 & $45 \pm 3$ & $92 \%$ & $44 \%$ \\
Li et al. [22]* & 51 & $55 \pm 33$ & $100 \%$ & $96.1 \%$ \\
\hline
\end{tabular}

*In this retrospective study, specimens had to be positive for RT-PCR to meet the inclusion criteria

RT-PCR, reverse transcription-polymerase chain reaction; CT, computed tomography

CT thorax on the same day, and they were divided into two groups - one group $(n=14)$ having SARS-CoV-2 reverse transcription-polymerase chain reaction (RT-PCR) positive report on the initial day and another group $(n=7)$ having initial negative RNA results but had positive results on further testing on the next day - and the study showed a statistically significant lower rates of pulmonary consolidation $(p<0.05)$ in the group having initial negative RT-PCR results [16]. The study did not find any difference either in distribution patterns of the CT lesions with unilateral versus bilateral or in the involvement of single versus multiple lobes between the two groups. The major stress of the study was to perform a chest CT scan in those clinically suspected patients having an initial negative RT-PCR report. CT scan findings have aided in diagnosing many such initial false-negative RT-PCR patients [17]. Ai et al.in their retrospective study [18] on 1014 patients who had RT-PCR from throat swab and CT chest done showed a sensitivity of $97 \%$ for chest CT in those having initial positive PCR results (95\%CI, 95-98\%; 580/601 patients), and it also showed a positive CT findings in $75 \%$ patients with initial negative PCR results. A case series of 51 patients [19] compared the CT chest findings with RT-PCR from throat swab and found 50/51 (98\%) patients having CT findings consistent with viral pneumonia-like peripheral, subpleural ground-glass opacities, often in the lower lobes. In this study, the detection rate for first time RT-PCR was only $71 \%$ (36/51, 95\%CI 56-83\%). A summary of a few of the published studies comparing CT chest and RT-PCR is summarized in Table 3 which is adopted and modified from a review article on radiological interpretations of COVID-19 [20].

The results from the above discussion conclude that neither RT-PCR nor CT chest should be relied upon as the sole criteria for diagnosis and both should be corroborated if suspicion remains on initial negative results of any one of these investigations.

Finally, to address this question of reinfection and immunity induction, a beautiful animal experiment has been done, and results are reassuring as it showed reinfection with SARS$\mathrm{CoV}-2$ in two rhesus macaques after their initial clinical recovery from the first infection of SARS-CoV-2 did not show viral replication in anal or nasopharyngeal swabs and the sera exhibited neutralizing activity against SARS-CoV-2 [23].

\section{Conclusion}

In conclusion, reinfection with SARS-CoV-2 seems unlikely taking into consideration our knowledge on viral neutralizing antibody duration from past respiratory illnesses, the type of specimen collection and technical errors associated with each component of swab testing, the methods used before discharging these patients, the presence of fecal viral RNA without evidence of replication-competent virus in fecal swabs, and finally the reassurance from the animal study. But till we have enough data to suggest that these patients are noninfective, we must maintain vigilance during the convalescence period also and must take into consideration the probability of genetic mutations as observed rather than reinfection by the same strain.

\section{Compliance with Ethical Standards}

Conflict of Interest The author declares that he has no conflict of interest.

Ethical Approval Not required.

\section{References}

1. Who.int. 2020. [online] Available at: <https://www.who.int/docs/ default-source/coronaviruse/situation-reports/20200420-sitrep-91covid-19.pdf?sfvrsn=fcf0670b_4> [Accessed 21 April 2020].

2. Jordan RE, Adab P, Cheng KK. Covid-19: risk factors for severe disease and death. BMJ. 2020;368:m1 198. https://doi.org/10.1136/ bmj.m1198.

3. Jwatch.org. NEJM Journal Watch: Summaries Of And Commentary On Original Medical And Scientific Articles From Key Medical Journals. 2020. [online] Available at: <https://www. 
jwatch.org/fw1 16502/2020/03/30/covid-19-update-viralpersistence-sputum-feces-ace $>$ [Accessed 21 April 2020].

4. Xu Y, Li X, Zhu B, Liang H, Fang C, Gong Y, et al. Characteristics of pediatric SARS-CoV-2 infection and potential evidence for persistent fecal viral shedding. Nat Med. 2020;26(4):502-5.

5. Koyama T, Platt D, Parida L. Variant analysis of COVID-19 genomes. [Submitted]. Bull World Health Organ. 2020. https://doi. org/10.2471/BLT.20.253591.

6. Chen D, Xu W, Lei Z, Huang Z, Liu J, Gao Z, et al. Recurrence of positive SARS-CoV-2 RNA in COVID-19: a case report. Int J Infect Dis. 2020;93:297-9.

7. An J, Liao X, Xiao T, Qian S, Yuan J, Ye H, Qi F, Shen C, Liu Y, Wang L, Cheng X, Li N, Cai Q, Wang F, Chen J, Liu Y, Wang Y, Zhang F, Fu Y, Tan X, Liu L, Zhang Z. Clinical characteristics of the recovered COVID-19 patients with re-detectable positive RNA test. [preprint]. 2020. Available at: https://www.medrxiv.org/ content/10.1101/2020.03.26.20044222v1. (Accessed: 08 June 2020).

8. Fu W, Chen Q, Wang T. Letter to the Editor: Three cases of redetectable positive SARS-CoV-2 RNA in recovered COVID-19 patients with antibodies. J Med Virol. 2020. https://doi.org/10. 1002/jmv.25968.

9. Petruzzi G, De Virgilio A, Pichi B, Mazzola F, Zocchi J, Mercante G, et al. COVID-19: Nasal and oropharyngeal swab. Head Neck. 2020. https://doi.org/10.1002/hed.26212 PMID: 32352180.

10. Loeffelholz MJ, Tang YW. Laboratory diagnosis of emerging human coronavirus infections - the state of the art. Emerg Microbes Infect. 2020;9:747-56. https://doi.org/10.1080/22221751.2020. 1745095.

11. Wang W, Xu Y, Gao R, Lu R, Han K, Wu G, et al. Detection of SARS-CoV-2 in different types of clinical specimens. JAMA. 2020;323(18):1843-1844. https://doi.org/10.1001/jama.2020. 3786.

12. Tang Y-W, Schmitz JE, Persing DH, Stratton CW. The laboratory diagnosis of COVID-19 infection: current issues and challenges. J Clin Microbiol. 2020;58(6):e00512-20. https://doi.org/10.1128/ JCM.00512-20.

13. Winichakoon P, Chaiwarith R, Liwsrisakun C, Salee P, Goonna A, Limsukon A, et al. Negative nasopharyngeal and oropharyngeal swabs do not rule out COVID-19. J Clin Microbiol. 2020;58(5): e00297-20. https://doi.org/10.1128/JCM.00297-20.
14. Anon. Clinical specimens: novel coronavirus 2019 (2019-nCoV). 2020. [online] Available at: https://www.cdc.gov/coronavirus/ 2019-nCoV/lab/guidelines-clinical-specimens.html.

15. Sethuraman N, Jeremiah SS, Ryo A. Interpreting diagnostic tests for SARS-CoV-2. JAMA. 2020. https://doi.org/10.1001/jama. 2020.8259 .

16. Chen D, Jiang X, Hong Y, Wen Z, Wei S, Peng G, et al. Can chest $\mathrm{CT}$ features distinguish patients with negative from those with positive initial RT-PCR results for coronavirus disease (COVID-19)? AJR Am J Roentgenol. 2020:1-5. https://doi.org/10.2214/AJR.20. 23012.

17. Huang P, Liu T, Huang L, Liu H, Lei M, Xu W, et al. Use of chest CT in combination with negative RT-PCR assay for the 2019 novel coronavirus but high clinical suspicion. Radiology. 2020;295:22-3.

18. Ai T, Yang Z, Hou H, Zhan C, Chen C, Lv W, et al. Correlation of chest CT and RT-PCR testing in coronavirus disease 2019 (COVID-19) in China: a report of 1014 cases. Radiology. 2020;26:200642. https://doi.org/10.1148/radiol.2020200642.

19. Fang Y, Zhang H, Xie J, Lin M, Ying L, Pang P, et al. Sensitivity of chest CT for COVID-19: comparison to RT-PCR. Radiology. 2020:200432. https://doi.org/10.1148/radiol.2020200432.

20. Shahzeb M, Khan A, Muhammad A. Detection of coronavirus disease (COVID-19) using radiological examinations. J Pure Appl Microbiol. 2020;14(Spl Edn) Available at: https://www. researchgate.net/publication/340998795 Detection of Coronavirus_Disease_COVID-19_using_Radiological Examinations.

21. Bernheim A, Mei X, Huang M, Yang Y, Fayad ZA, Zhang N, et al. Chest CT findings in coronavirus disease-19 (COVID-19): relationship to duration of infection. Radiology. 2020;295:200463. https:// doi.org/10.1148/radiol.2020200463.

22. Li Y, Xia L. Coronavirus disease 2019 (COVID-19): role of Chest CT in diagnosis and management. Am J Roentgenol. 2020;214:17. https://doi.org/10.2214/AJR.20.22954.

23. Ota M. Will we see protection or reinfection in COVID-19? Nat Rev Immunol. 2020; [online] Available at: <https://www.nature. com/articles/s41577-020-0316-3\#citeas> [Accessed 8 May 2020].

Publisher's Note Springer Nature remains neutral with regard to jurisdictional claims in published maps and institutional affiliations. 